\title{
Tree Establishment: A Review of Some of the Factors Affecting Transplant Survival and Establishment
}

\author{
Daniel K. Struve
}

\begin{abstract}
Transplant success and tree establishment depend on a chain of events from propagation, to production, to harvest, to shipping, to maintenance on the job site, to transplanting techniques, to aftercare. Failure to follow proper practices at any step in this sequence will compromise transplant success and establishment. This article reviews some of the factors that induce transplant shock and slow establishment of transplanted nursery stock such as root and mineral nutrient loss, soil moisture stress and xylem vessel cavitation, and methods used to reduce transplant shock.
\end{abstract}

Key Words. Biostimulants; establishment; root growth potential; transplanting.

This article discusses some of the causes of transplant shock (root loss, root system morphology, phenology of shoot and root development, and soil moisture stress), the measures of establishment, the benefits of biostimulants, and the effect of tree caliper on red oak establishment. This review is not comprehensive; it uses examples from the author's research with red oak (Quercus rubra L.), which is considered a coarse-rooted species and relatively difficult to transplant. Also, the earlier citations that demonstrate a principle are given for a historical perspective, with apologies to authors of more recent citations.

\section{Transplant Shock}

Transplant shock is a condition of distress from injuries, depletion, and impaired functions; a process of recovery; and a period of adaptation to a new environment (Rietveld 1989). Transplant shock is initiated by root system loss resulting from either bare root or balled-and-burlapped harvest (Watson and Sydnor 1987). Root loss reduces the tree's ability to absorb water and mineral nutrients and causes the loss of storage compounds such as carbohydrates and mineral nutrients. For instance, up to $50 \%$ of a 1-year-old red oak (Quercus rubra L.) root system is storage carbohydrate (Larson 1978). By late September, the root system of a 1 -year-old red oak seedling contains up to $60 \%$ of the seedlings total nitrogen (Larimer and Struve 2002) and an estimated $80 \%$ of seedling's nitrogen content after defoliation.

When dormant deciduous plant material is transplanted, transplant shock severity is also related to the relative timing between the initiation of shoot growth and first root regeneration. Under benign greenhouse conditions, shoot growth in transplanted (root pruned) red oak seedlings preceded first root regeneration by as many as 33 days (Johnson et al. 1984). Transplanted red oak seedlings adjusted to transplant-induced water stress by reducing leaf area thereby maintaining net assimilation, conductance, and transpiration (on a $\mathrm{cm}^{2}$ leaf surface area basis) similar to that of untransplanted seedlings (Struve and Joly 1992). However, because of significantly reduced leaf surface area of transplanted seedlings (1.8 to 2.4 times less leaf area), estimated whole plant transpiration and net assimilation rates are higher in untransplanted seedlings. For species with fibrous root systems, the delay between budbreak and first root regeneration is less because first root regeneration occurs through elongation of existing root tips and not from adventitious root regeneration (Arnold and Struve 1989).

There are two types of root regeneration: elongation of existing root tips and initiation of adventitious roots and their subsequent elongation (Stone and Shubert 1959). Initial seedling survival is dependent on the elongation of existing roots, which is independent of the season of the year and occurs whenever soil moisture and temperatures permit. Establishment is dependent on initiation and elongation of new roots, which is confined primarily to late winter and early spring, even when nonlimiting soil moisture and temperatures are provided. Thus, fibrous-rooted species are easier to transplant then coarse-rooted species because they have higher root regeneration potential resulting from greater numbers of rapidly regenerating intact root tips at harvest. In contrast, coarse-rooted species have few intact root tips after harvest. Thus, root regeneration results from new root initiation and subsequent elongation.

Root regeneration potential is significantly reduced by even moderate $(-0.4 \mathrm{MPa})$ soil moisture stress (Larson and Whitmore 1970). Soil moisture stress also reduces root elongation. Root elongation is also inhibited in compacted soils and the root growth inhibition made worse by the combination of soil compaction and low soil moisture content (Bennie 1991).

Another physiological factor affecting spring-transplanted nursery stock in temperate regions is xylem dysfunction, especially for ring porous species such as Quercus. For red oak, there is a $20 \%$ loss of hydraulic conductivity in current-season shoots as a result of cavitation by August (Cochard and Tyree 1990). After the first hard frost, cavitation is greater than $90 \%$. Thus, red oak must form new xylem in spring to restore hydraulic conductivity. It seems likely that rough handling of nursery stock in early spring would damage the developing xylem and compromise hydraulic conductivity and, consequently, survival and establishment. Also, summer digging of oaks would result in cavitation of large xylem vessels and would compromise survival. Defuse porous species are less susceptible to cavitation than ringporous species (Cochard and Tyree 1990) and, by inference, suffer less cavitation when handled roughly or summer dug than ring-porous species. 


\section{Establishment}

There are several measures of plant establishment: re-establishment of the tree height-to-root spread ratio (Watson 1985; Gilman 1997), resumption of a pretransplant shoot elongation rate (Struve and Joly 1992), or restoration of shoot xylem water potential relative to untransplanted control trees (Beeson 1994; Beeson and Gilman 1992; Gilman 1992). The re-establishment of the branch-to-root spread ratio is most dependent on the rate of root elongation because shoot growth is typically suppressed during the establishment phase. The rate of establishment, under nonlimiting edaphic conditions, is dependent on the length of the growing season, which affects the root elongation potential. Maintaining adequate soil moisture will also increase the root elongation potential. Because of the longer growing season in Florida (USDA Plant Hardiness Zone 9), a $5.1 \mathrm{~cm}$ (2 in) caliper tree will establish in 6 months, whereas in northern Illinois (USDA Plant Hardiness Zone 5), establishment would take 24 months (Gilman 1997). The establishment period in USDA Plant Hardiness Zone 5 is based on the assumption of 18 in of root elongation per year.

\section{Missouri Gravel Bed System}

To determine the root elongation potential of transplanted $7.6 \mathrm{~cm}$ (3 in) diameter red oak in USDA Plant Hardiness Zone 5, red oak trees were balled and burlapped in April and heeled-in beds of pea gravel or wood chips in a modified Missouri gravel bed system (Starbuck et al. 2005). Before heeling-in, half the trees were bare-rooted by washing the soil from the root systems resulting in four treatment combinations: bare root or balled-and-burlapped trees combined with heeling-in either wood chips or pea gravel. In September, the plants were removed from the heeling-in areas. Regenerated root lengths were measured and shoot growth for the year before transplanting and for the next 3 years was measured.

Of the 24 trees transplanted, 19 survived. All mortality occurred in the bare root trees heeled-in the fresh wood chips. High temperatures resulting from the composting wood chips killed the bare root trees. However, under the benign conditions of the heeling-in beds, root growth of the five longest roots per tree ranged between 52 and $61 \mathrm{~cm}$ (21 and 24 in) for the bare root and balled-and-burlapped trees, respectively, heeled-in pea gravel. All plants had well-established mycorrhizal associations, which formed despite weekly fertilization with $100 \mathrm{mg} / \mathrm{L}$ nitrogen water-soluble fertilizer. After measuring, the trees were transplanted to a lawn panel on campus and growth followed for the next 3 years. Based on the lengths of root regenerated between April and September, the trees will have re-established the 3:1 root spread-to-height caliper ratio the second year after transplanting, which is significantly faster than that estimated for 3 in caliper trees in USDA Plant Hardiness Zone 5. Alternatively, if establishment was based on the resumption of the pretransplant shoot elongation rate, then the trees were established within 1 to 3 years of transplanting. Another benefit of the heeling-in period was development of a root system that necessitated digging a wide planting hole with gently sloping sides, the type recommended in the Tree Planting Best Management Practices (Watson and Himelick 2005). A Missouri Gravel Bed system may aid in the establishment of difficult-to-transplant trees, in which the critical stages of root regeneration occur under benign conditions.

\section{Tree Size}

It is accepted that large-caliper trees take more time to establish than small-caliper trees, in part as a result of the greater time required to re-establish the preharvest root diameter-to-tree height ratio. However, there are confounding factors to consider when comparing the time to establishment of small- and largecaliper trees. These factors include the following.

Large-caliper trees are typically the genetic runts in a nursery block. Faster growing trees are harvested at smaller caliper sizes because they are the first to reach salable size. This is true for both clonal material in which within-clone differences in tree size can be attributed to differences in the degree of graft incompatibility, in root stock vigor, in root system quality among rooted cuttings, or in pathogen load.

Large-caliper trees are in a reduced state of vigor from assaults associated with previous harvesting of the faster growing trees harvested at smaller caliper size. These assaults include compacted soils, root pruning, and mechanical damage (Struve et al. 2000). Additionally, irrigation systems are typically removed (or damaged) and cultural practices such as pest control and fertilization may be curtailed after the initial harvests have begun. Also, if large-caliper trees have not been transplanted every 3 to 4 years during production, survival and establishment may be compromised because larger diameter roots are severed. Large-diameter roots regenerate roots slower that small-diameter ones (Johnson et al. 1984). Regular root pruning increases root system density relative to unroot-pruned trees (Watson and Sydnor 1987).

In an experiment comparing the survival and posttransplant growth of 7.6 to $10.2 \mathrm{~cm}$ ( 3 to $4 \mathrm{in}$ ) and 3.8 to $5.1 \mathrm{~cm} \mathrm{(1.5} \mathrm{to} 2$ in caliper trees, it was found that larger-caliper trees had higher mortality than smaller caliper trees (Struve et al. 2000). However, based on the prediction equations estimating caliper growth (using the data from the 4 years after transplanting), the surviving large-caliper trees have greater caliper increase than transplanted small-caliper trees. The untransplanted small-caliper control trees are predicted to reach similar size as the large-caliper transplanted trees 11 years after transplanting. In this study, many of the confounding effects associated with large-caliper tree production were avoided. Thus, at least in this study, there was no evidence that the surviving large-caliper trees established slower than the small-caliper trees.

\section{Biostimulants}

Biostimulants are proprietary nonnutritional products that are marketed to mediate the effects of plant stress. Most products are mixtures of plant hormones, humates, manures, and/or sea kelp extracts. Their benefit as transplanting aids has been mixed (see Sammons and Struve 2004). In a summer digging study with Goldenraintree (Koelreuteria paniculata Laxm.), field-grown trees were treated with Bioplex (Mt. Joy, PA) as foliar spray, soil drench, a combination of foliar spray, and soil drench 3 days before harvestings as balled-and-burlapped trees or left untreated (Sammons and Struve 2005). Bioplex treatment reduced transpiration for 3 days after application, relative to untreated plants. After 3 days, the transpiration rate of treated plants was similar to untreated plants. Three days after treatment, some of the plants were dug, whereas others were left untransplanted. Digging Bioplex-treated and untreated plants significantly reduced transpiration relative to nondug control trees. Despite the undersized balls $(55.9 \mathrm{~cm}$ [22 in] diameter balls on $6.1 \mathrm{~cm}$ [2.4 in] caliper trees), minimal aftercare, 
and the hot August temperatures, transplanting survival was $100 \%$. The only treatment differences were that transplanted trees the year after transplanting had smaller caliper and shoot increase (relative to the year before transplanting) than untransplanted trees.

There are other factors that affect transplant survival and regrowth such as planting depth, mulching, backfill amendments, and site quality; these practices are not discussed in this review. Planting nursery stock planted too deep in the nursery or at the planting site reduces survival and long-term performance in the landscape. However, improper planting depth results from improper nursery production or landscape installation practices. It can be corrected in the nursery by either planting at the proper depth and, if needed, combined with staking to ensure needed mechanical support, or, at harvest, by removing excess soil before the soil ball is formed. At the landscape site, the soil ball can be nondestructively probed to determine the level of the structural roots and planted so that these roots are within 2.5 to $7.5 \mathrm{~cm}$ (1 to 3 in) of the soil surface (Watson and Himelick 2005) or if the structural roots are too deep, the nursery stock should be rejected. However, at least in the short term, these practices cost money. Thus, contract specifications should incorporate best management practices and those practices should be enforced by project managers.

Mulching helps establishment of transplants where minimal aftercare is provided (Chalker-Scott 2007). Mulching transplanted trees helps reduce mechanical and soil moisture stresses. No more than $5 \mathrm{~cm}$ ( 2 in) of mulch should be placed over the root system (Watson and Himelick 2005). Backfill amendments are not needed when the native soil is of high quality. In poorquality soils, amending the planting site is preferred to amending the backfill. There is abundant anecdotal evidence that site quality affects transplant survival and establishment, but soil quality descriptors, design, and construction specifications that imitate native soil profiles remain elusive (Craul 1999).

\section{SUMMARY}

These studies suggest that with careful handling, transplant shock can be greatly reduced, even if plants that are transplanted in full leaf with undersized root balls and during periods of high summer temperatures. Perhaps improper handling during harvest, shipping, and at the job site is more responsible for inducing transplant shock than the putative biologic limitations of the plant material. There is ample anecdotal evidence that site quality significantly affects transplant survival and establishment, but remedial soil prescriptions have not been developed. Finally, transplant success and establishment in the landscape is dependent on a chain of events from propagation, to production, to harvest, to shipping, to maintenance on the job site, to transplanting techniques, to aftercare. Failure to follow proper practices at any step in this sequence will compromise transplant success and establishment. There is no "silver bullet" that compensates for improper practices.

Acknowledgment. I thank the Ohio Agricultural Research and Development Center, The Ohio State University.

\section{LITERATURE CITED}

Arnold, M.A., and D.K. Struve. 1989. Green ash establishment following transplant. Journal of the American Society for Horticultural Science 114:591-595.

Beeson, R.C. 1994. Water relations of field-grown Quercus virginiana Mill. from preharvest through containerization and 1 year into a landscape. Journal of the American Society for Horticultural Science 119:169-174.
Beeson, R.C., and E.F. Gilman. 1992. Water stress and osmotic adjustment during post-digging acclimatization of Quercus virginiana produced in fabric containers. Journal of Environmental Horticulture 19:208-214.

Bennie, A.T.P. 1991. Growth and mechanical impedance. In: Waisel, Y., A. Eshel, and U. Kafkafi (Eds.). Plant Roots: The Hidden Half. Marcel Dekker, New York, NY. 948 pp.

Chalker-Scott, L. 2007. Impact of mulches on landscape plants and the environment-A review. Journal of Environmental Horticulture 25:234-249.

Cochard, H., and M. Tyree. 1990. Xylem dysfunction in Quercus: Vessel sizes, tyloses, cavitation and seasonal changes in embolism. Tree Physiology 6:393-407.

Craul, P.J. 1999. Urban Soils: Applications and Practices. John Wiley \& Sons, New York, NY.

Gilman, E.F. 1992. Establishing trees in the landscape, pp. 69-77. In: Neely, D., and G.W. Watson (Eds.). The Landscape Below Ground: Proceeding of an International Conference on Tree Root Development in Urban Soils. International Society of Arboriculture, Champaign, IL.

1997. Trees for Urban and Suburban Landscapes. Delmar Publishers, Albany, NY.

Johnson, P.S., S.L. Novinger, and W.G. Mares. 1984. Root, shoot and leaf area growth potentials of northern red oak planting stock. Forest Science 30:1017-1026.

Larimer, J., and D. Struve. 2002. Growth, dry weight and nitrogen distribution of red oak and 'Autumn Flame' red maple under different fertility levels. Journal of Environmental Horticulture 20:28-35.

Larson, M.M., 1978. Effects of late-season defoliation and dark periods on initial growth of planted northern red oak seedlings. Canadian Journal of Forest Research 8:67-72.

Larson, M.M., and F.W. Whitmore. 1970. Moisture stress affects root regeneration and early growth of red oak seedlings. Forest Science 16:495-498.

Rietveld, W.J. 1989. Transplanting stress in bare root conifer seedlings: Its development and progression to establishment. Northern Journal of Applied Forestry 6:99-107.

Sammons, J.D., and D.K. Struve. 2004. Effect of Bioplex ${ }^{\mathrm{TM}}$ on transplant success of non-dormant red oak (Quercus rubra L.). Journal of Environmental Horticulture 22:197-201.

Sammons, J.D., and D.K. Struve. 2005. Effect of Bioplex ${ }^{\mathrm{TM}}$ on transplant success and recovery of summer-dug Goldenraintree. Journal of Environmental Horticulture 23:59-62.

Starbuck, C., D.K. Struve, and H. Mathers. 2005. Bareroot and balledand-burlapped red oak and green ash can be summer transplanted using the Missouri Gravel Bed system. HortTechnology 15:9-14.

Stone, E.C., and G.H. Schubert. 1959. Root regeneration by Ponderosa Pine seedlings lifted at different times of the year. Forest Science 5:322-332.

Struve, D.K., L. Burchfield, and C. Maupin. 2000. Survival and growth of transplanted large- and small-caliper red oaks. Journal of Arboriculture 26:162-169.

Struve, D.K., and R.J. Joly. 1992. Transplanted red oak seedlings mediate transplant shock by reducing leaf surface area and altering carbon allocation. Canadian Journal of Forest Research 22:1441-1448.

Watson, G. 1985. Tree size affects root regeneration and top growth after transplanting. Journal of Arboriculture 11:37-40.

Watson, G., and E.B. Himelick. 2005. Best Management Practices: Tree Planting. ANSI A300 Part 6: Tree, Shrub and Other Woody Plant Maintenance-Standard Practices (Transplanting). International Society of Arboriculture, Champaign, IL.

Watson, G., and T.D. Sydnor. 1987. The effect of root pruning on the root system of nursery trees. Journal of Arboriculture 13:126-130.

Daniel K. Struve

Department of Horticulture and Crop Science

2001 Fyffe Court

The Ohio State University

Columbus, OH 43210, U.S.

struve.1@osu.edu 
Résumé. Le succès de la transplantation et de la reprise d'un arbre dépend d'une chaîne d'événements depuis la propagation, la production, la récolte, le transport, l'entretien sur le chantier, les techniques de plantation jusqu'aux soins post-plantation. Le défaut de suivre de bonnes pratiques de soins à n'importe quelle étape de cette séquence va compromettre le succès de la plantation et de la reprise. Cet article fait une revue de certains des facteurs qui induisent un choc de plantation et une reprise plus lente de végétaux de pépinière tels que la perte de racines et d'éléments minéraux, le stress en regard de l'humidité du sol et la cavitation des vaisseaux de xylème, de même que des méthodes pour réduire le choc de plantation.

Zusammenfassung. Der Erfolg einer Baumverpflanzung und der Standortetablierung hängt von einer Kette von Ereignissen, wie Anzucht, Produktion, Ernte, Transport, Anwachspflege, Transplantationstechniken bis hin zu Fertigstellungspflege, ab. Wird an irgendeiner Stelle nicht ordentlich nach anerkannten
Regeln der Technik gearbeitet, ist der Anwachserfolg und Standortetablierung gefährdet. Dieser Artikel gibt einen Überblick über einige dieser Faktoren, die einen Transplantationsschock und langsame Entwicklung von verpflanzter Baumschulware verursachen können durch Wurzel- und Nährstoffverluste, Bodenfeuchtigkeitsstress und Xylemkavitation sowie Methoden, die den Transplantationsschock mindern.

Resumen. El éxito del trasplante y el establecimiento de los árboles dependen de una cadena de eventos de propagación, producción, cosecha, envío, mantenimiento en el sitio del trabajo, técnicas de trasplante y cuidados posteriores. La falla en prácticas apropiadas en cualquier paso de esta secuencia comprometerá el éxito del trasplante y el establecimiento. Este artículo revisa algunos de estos factores que inducen el shock de trasplante y el lento establecimiento de árboles trasplantados de viveros como pérdidas de raíces y minerales, estrés de humedad del suelo y bloqueo de los vasos del xilema, así como los métodos usados para reducir el shock de trasplante. 